\title{
Al-Mg 合金板の引張歪模様に関する研究*
}

\author{
一主としてランダム・マーキングの発生条件一
}

\section{青木顕一郎** 勝田 基嗣**・菅又 信**}

\author{
Studies on strecher strain markings of $\mathrm{Al}-\mathrm{Mg}$ alloy sheets* \\ - Conditions for generation of random marking- \\ UDC 669. 715'721-12:539. 379 \\ AOKI Kenichiro**, KATSUTA Mototsugu** and SUGAMATA Makoto**
}

It is known that $\mathrm{Al}-\mathrm{Mg}$ alloy sheets produce stretcher strain markings in stretching process. The stretcher strain markings are due to yields of two types; type-A and type-B. The type-A produces random marking and type-P produces parallel marking.

In the process of pressing, the random marking appears in the range of very slight strain and bring about a serious defect.

The authors chiefly studied the conditions for the generation of the random marking.

The results obtained were as follows:

(1) The random marking produced during stretching was observed on fine-grained (under 0.04 or $0.05 \mathrm{~mm}$ ) and recrystallized alloy sheets; but it was scarcely observed on coarse grained (above $0.1 \mathrm{~mm}$ ) sheets.

(2) The relation between the generation of random marking and the structural change during isothermal ageing (at 200 and $175^{\circ} \mathrm{C}$ ) was also studied. As a result, the marking was observed on all water-quenched alloy sheets. However, it was not observed on $\mathrm{Al}-8 \% \mathrm{Mg}$ alloy sheets after the start of a subsequent age-hardening and its disappearance was continued until overageing. Whereas, the marking was always observed during 140 days of ageing on alloy sheets containing less than $6 \%$ of magnesium.

(3) The grain size at which the random marking was observed depended upon the addition of copper as a third element. The additional copper $(0.1 \sim 0.5 \%)$ elevated the upper limit of grain size range beyond $0.04 \sim$ $0.05 \mathrm{~mm}$.

(4) The age-hardening of $\mathrm{Al}-8 \% \mathrm{Mg}$ alloy sheets was accelerated by additional copper as a third element; but, the sheets of containing less than $6 \%$ of magnesium were not accelerated by copper.

(Received Feb. 25, 1971)

\section{1. まえがき}

$\mathrm{Al}-\mathrm{Mg}$ 合金板を引張加工した場合, Photo. 1 に示す ような䄳模様 (Stretcher-Strain-Marking) を発生し1), 応力一歪曲線に降状点が現われることが報告されてい

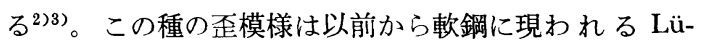
ders Line と呼ばれるクサビ型の模様と類似するもので, $\mathrm{Al}-\mathrm{Mg}$ 系の合金ではランダム・マーキングとして知ら れている。このマーキングの発生は，材料の降状点現象 の発生機構と関連があり, 非常に興味ある問題である。
工業的に見れば，この模様の発生は平滑な平面の外観を そこなうので，はなはだ好ましくない。Al-Mg合金のラ ンダム・マーキングに関するこれまでの研究結果によれ ば1) 4)，以下のようにまとめることができる。

1） ランダム・マーキングの発生には，主な合金組成 である $\mathrm{Mg}$ 自身が関与する。その $\mathrm{Mg}$ 量は $0.6 \sim 0.9(\mathrm{wt} \%)$ 付近から発生し, 以後, $\mathrm{Mg}$ 量が増加してもマーキング の強度（ここでは局部収縮率）はほとんど一定である。

2）マーキングは前処理として材料に焼入れを行なう ことによつて除去しうる。

* 軽金属学会第22，23，24回の各大会で発表した。

** 日本大学生産工学部（習志野市）College of Industrial Technology, Nihon Univ. (Narashino) 
3）マーキングは細かい結晶からなる（0.04 $\mathrm{mm}$ $0.05 \mathrm{~mm}$ 以下) 再結晶した材料に発生する。

4）粗大結晶粒からなる材料または加工材・加工後時 効した材料にはあらわれない。

5）マーキング発生の原因を“粒界における高濃度 の $\mathrm{Mg}$ の存在が，結晶粒から結晶粒へのすべりの伝播の Blocking をもたらす”ためであると説明している。

今回の筆者の研究結果によれば, 焼入れ状態および焼 入れ後人工時効したものにもランダム・マーキングの発 生を見た。これらの現象は以前の結果と異なるものであ る。いすれれしても，ランダム・マーキングに関する明 確な知識はいまだ確立されていない。本論文では, ラン ダム・マーキングの発生条件について研究した結果を報 告する。

\section{2. ランダム・マーキング発生の実証的研究}

\section{1 試料作製および実験方法}

$\mathrm{Al}-\mathrm{Mg}$ 合金板に発生するといわれる引張丕模様を観 察する目的で Table 1 のような化学組成からなる種々 の $\mathrm{Al}-\mathrm{Mg}$ 合金板を作製した。これらの合金板の作製に は，99.99\%のアルミニウム地金と $99.99 \%$ のグネシウ 么地金を使用した。各種の合金は溶解後，70×60×15 $\mathrm{mm}$ の金型に鋳造し, $420^{\circ} \mathrm{G}$ で $24 \mathrm{hrs}$. の均一加熱処理 後, 約 $12 \mathrm{~mm}$ まで旋削にて面取りし, その後 $450^{\circ} \mathrm{C}$ で $1 \mathrm{hr}$.の中閒焼きなましを繰返しながら板厚 $6 \mathrm{~mm}$ まで 圧延し, 最終圧延で加工度約 $90 \%(0.6 \mathrm{~mm})$ の板材と した。これらの板から Fig. 1 のような小型の引張 試験

Table 1 Compositions of $\mathrm{Al}-\mathrm{Mg}$ alloys.

\begin{tabular}{cc|c|c}
\hline \multirow{2}{*}{ Specimen Number } & \multicolumn{2}{|c}{ Chemical Composition } \\
\cline { 2 - 3 } & Mg (\%) & $\mathrm{Al}(\%)$ \\
\hline \multirow{2}{*}{ No. } & 1 & 0.80 & Remainder \\
& 2 & 1.85 & $\prime \prime$ \\
3 & 2.00 & $\prime \prime$ \\
4 & 3.50 & $\prime \prime$ \\
5 & 5.60 & $\prime \prime$ \\
6 & 7.97 & $\prime$ \\
\hline
\end{tabular}

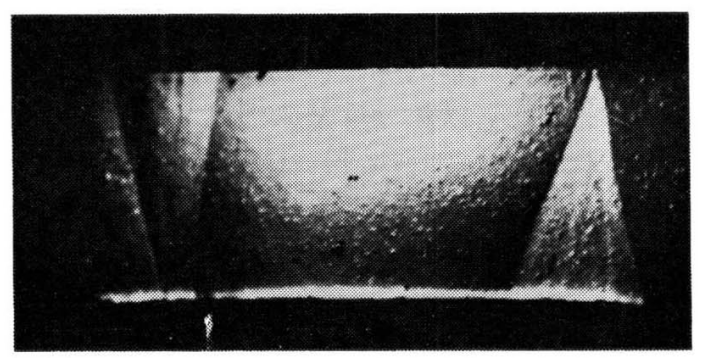

Photo. 1 Stretcher strain marking. (Random marking)

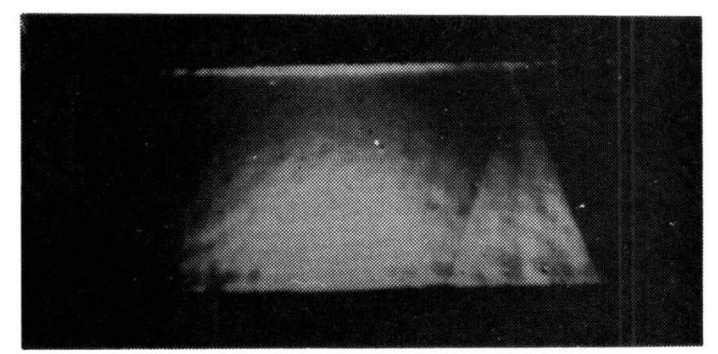
工初期にランダム・マーキングを発生するという事実が 実証されると共に，二，三の興味ある結果も示された。

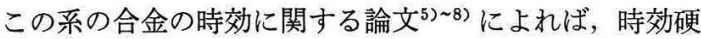
化が認められるようであるが，析出相の析出そのものの

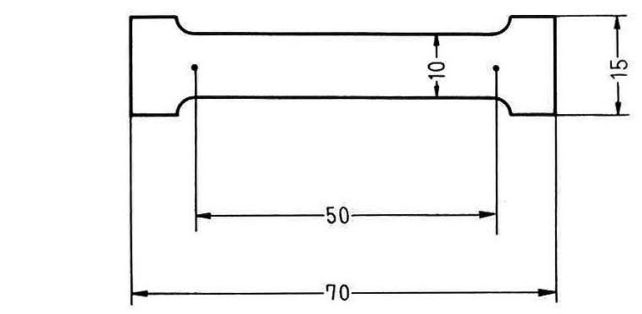

Fig. 1 Specimen-sizc ( $\mathrm{mm})$.

1） $0.04 \mathrm{~mm}$ 以下の結晶粒からなるこの種の合金板に はランダム・マーキングが発生する。

2）炉冷，空冷，水焼入れのいずれの熱処理を行なつ てもランダム・マーキングは発生する。

3) $150^{\circ} \mathrm{C}, 200^{\circ} \mathrm{C}, 250^{\circ} \mathrm{C}, 300^{\circ} \mathrm{C}$ の各温度による数時 間にわたる人工時効後もランダム・マーキングは発生す る。

\section{3. ランダム・マーキング発生におよぼす恒温 時効の影響}

前節 2 では, $\mathrm{Al}-\mathrm{Mg}$ 合金板を引張り加工する と, 加 
Table 2 Stretching characteristic of heat-treated alloys.

\begin{tabular}{|c|c|c|c|}
\hline Specimen Number & Heat Treatment & $\begin{array}{l}\text { Grain Size } \\
\quad(\mathrm{mm})\end{array}$ & $\begin{array}{c}\text { Appearance of } \\
\text { Specimens } \\
\text { during Stretching } \\
\text { (Extension } 0 \sim 2 \%)\end{array}$ \\
\hline $\begin{array}{c}\text { No. } 1 \\
(0.80 \% \mathrm{Mg})\end{array}$ & $\begin{array}{l}2 \text { hrs. at } 280^{\circ} \mathrm{C} \text {; F.C. } \\
3 \text { hrs. at } 300^{\circ} \mathrm{C} \text {; F.C. } \\
2 \text { hrs. at } 325^{\circ} \mathrm{C} \text {; F.C. }\end{array}$ & $\begin{array}{l}0.040 \\
0.040 \\
0.051\end{array}$ & $\begin{array}{c}\text { N.M. } \\
\text { " } \\
\text { " }\end{array}$ \\
\hline $\begin{array}{c}\text { No. } 2 \\
(1.85 \% \mathrm{Mg})\end{array}$ & $\begin{array}{l}2 \mathrm{hrs} . \text { at } 325^{\circ} \mathrm{C} \text {; F.C. } \\
2 \mathrm{hrs} \text { at } 325^{\circ} \mathrm{C} \text {; W.Q. } \\
2 \mathrm{hrs} \text {. at } 325^{\circ} \mathrm{C} \text {; W.Q; aged } 4 \text { hrs. at } 150^{\circ} \mathrm{C} \\
2 \text { hrs. at } 325^{\circ} \mathrm{C} \text {; W.Q; aged } 2 \text { hrs. at } 200^{\circ} \mathrm{C} \\
2 \text { hrs. at } 325^{\circ} \mathrm{C} \text {; W.Q; aged } 1 \mathrm{hr} \text {. at } 300^{\circ} \mathrm{C} \\
2 \text { hrs. at } 300^{\circ} \mathrm{C} \text {; W.Q; }\left(15^{\circ} \mathrm{C}\right)\end{array}$ & $\begin{array}{l}- \\
- \\
- \\
-\end{array}$ & $\begin{array}{l}\text { R.M. } \\
\text { N.M. } \\
\quad \text { " } \\
\quad \text { " } \\
\text { R.M. } \\
\text { N.M. }\end{array}$ \\
\hline $\begin{array}{c}\text { No. } 3 \\
(2.00 \% \mathrm{Mg})\end{array}$ & $\begin{array}{l}2 \text { hrs. at } 325^{\circ} \mathrm{C} \text {; F.C. } \\
2 \text { hrs. at } 325^{\circ} \mathrm{C} \text {; W.Q. } \\
2 \text { hrs. at } 300^{\circ} \mathrm{C} \text {; W.Q. } \\
2 \text { hrs. at } 325^{\circ} \mathrm{C} \text {; W.Q. aged } 4 \text { hrs. at } 150^{\circ} \mathrm{C} \\
2 \text { hrs. at } 400^{\circ} \mathrm{C} \text {; W.Q. }\end{array}$ & $\begin{array}{l}- \\
0.037 \\
- \\
- \\
0.066\end{array}$ & $\begin{array}{c}\text { R.M. } \\
\text { " } \\
\text { " } \\
\text { " } \\
\text { N.M. }\end{array}$ \\
\hline $\begin{array}{c}\text { No. } 4 \\
(3.50 \% \mathrm{Mg})\end{array}$ & $\begin{array}{l}2 \text { hrs. at } 300^{\circ} \mathrm{C} \text {; W.Q. } \\
2 \text { hrs. at } 300^{\circ} \mathrm{C} \text {; F.C. } \\
0.5 \text { hrs. at } 300^{\circ} \mathrm{C} \text {; W.Q. } \\
2 \text { hrs. at } 325^{\circ} \mathrm{C} \text {; W.Q. } \\
2 \text { hrs. at } 350^{\circ} \mathrm{C} \text {; W.Q. } \\
2 \text { hrs. at } 360^{\circ} \mathrm{C} \text {; W.Q. } \\
2 \text { hrs. at } 375^{\circ} \mathrm{C} \text {; W.Q. } \\
2 \text { hrs. at } 400^{\circ} \mathrm{C} \mathrm{W} . Q .\end{array}$ & $\begin{array}{l}- \\
- \\
- \\
- \\
- \\
- \\
0.075 \\
0.089\end{array}$ & $\begin{array}{c}\text { R.M. } \\
\text { " } \\
\text { " } \\
\text { " } \\
\text { " } \\
\text { N.M. } \\
\text { " }\end{array}$ \\
\hline $\begin{array}{c}\text { No. } 5 \\
(5.60 \% \mathrm{Mg})\end{array}$ & $\begin{array}{l}2 \text { hrs. at } 325^{\circ} \mathrm{C} \text {; F.C. } \\
2 \text { hrs. at } 325^{\circ} \mathrm{C} \text {; A.C. } \\
2 \text { hrs. at } 325^{\circ} \mathrm{C} \text {; W.Q. } \\
2 \text { hrs. at } 400^{\circ} \mathrm{C} \text {; W.Q. } \\
2 \text { hrs. at } 400^{\circ} \mathrm{C} \text {; W.Q.; aged } 0.5 \text { hrs. at } 200^{\circ} \mathrm{C} \\
2 \text { hrs. at } 400^{\circ} \mathrm{C} \text {; W.Q.; aged } 0.5 \text { hrs. at } 250^{\circ} \mathrm{C} \\
2 \text { hrs. at } 400^{\circ} \mathrm{C} \text {; W.Q.; aged } 0.5 \text { hrs. at } 300^{\circ} \mathrm{C} \\
2 \text { hrs. at } 400^{\circ} \mathrm{C} \text {; W.Q.; aged } 18 \text { hrs. at } 250^{\circ} \mathrm{C} \\
2 \text { hrs. at } 425^{\circ} \mathrm{C} \text {; W.Q. }\end{array}$ & $\begin{array}{l}0.036 \\
0.031 \\
- \\
0.041 \\
- \\
- \\
- \\
- \\
0.047\end{array}$ & $\begin{array}{c}\text { R.M. } \\
\text { " } \\
\text { " } \\
\text { " } \\
" \\
" \\
\text { " } \\
\text { N.M. }\end{array}$ \\
\hline $\begin{array}{c}\text { No. } 6 \\
(7.97 \% \mathrm{Mg})\end{array}$ & 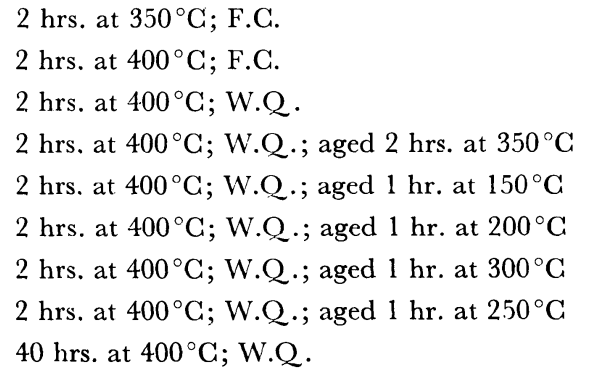 & $\begin{array}{l}0.036 \\
- \\
- \\
- \\
- \\
- \\
- \\
- \\
-\end{array}$ & $\begin{array}{c}\text { R.M. } \\
\text { " } \\
\text { " } \\
\text { " } \\
\text { " } \\
\text { " } \\
\text { " } \\
\text { " }\end{array}$ \\
\hline
\end{tabular}

A.C.; Air Cooled F.C.; Furnace Cooled W.Q.; Water Quenched N.M.; NO Marking R.M.; Random Marking 
硬化はかなりあとで開始され，析出はまず粒界に局部析 出を抢こし, ついで全面析出となり, 最後に過時効の段 階に入つて析出物は凝集するといわれている。これらの 析出過程の組織変化とランダム・マーキングの発生との 関連は，おおいに興味ある問題である。これらの問題を 説明するために，第一段階として，この種の合金の時効 曲線を調べた。時効温度は硬化を促進するために，200 ${ }^{\circ} \mathrm{C}$ の比較的高温を選んだ。使用した試料は Table 1 の No. 4, 5, 6 の 3 種の Al-Mg 合金で，2.1で述べたと同様

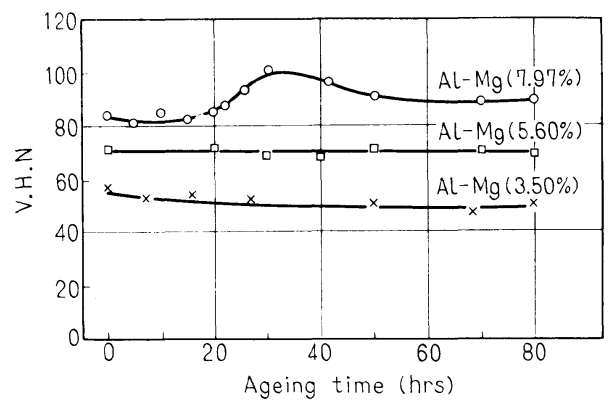

Fig. 2 Age-hardening curves of various $\mathrm{Al}-\mathrm{Mg}$ alloys at $200^{\circ} \mathrm{C}$.
の方法で試料を作製した。試料の溶体化処理温度は, $\mathrm{Al}-\mathrm{Mg}$ 合金状態図 ${ }^{93}$ から $\mathrm{Mg}$ 含有量に対応した溶解度曲 線上，約 $50^{\circ} \mathrm{C}$ 高い温度を採用し，それぞれ，3.50\% $\mathrm{Mg}$ 量 のものは $300^{\circ} \mathrm{C}, 5.60 \% \mathrm{Mg}$ 量のものは $350^{\circ} \mathrm{C}, 7.97 \% \mathrm{Mg}$ 量のものは $400^{\circ} \mathrm{C}$ とした。いずれも，1 時間焼きなまし 後, 直ちに水焼入れを行なつた。Fig. 2 は $3.50 \%, 5.60$ $\%, 7.97 \%$ の $\mathrm{Mg}$ 量を含む 3 種の $\mathrm{Al}-\mathrm{Mg}$ 合金の $200^{\circ} \mathrm{C}$ に おける時効硬化曲線である。Fig. 2 から, $\mathrm{Mg}$ 量の多い $7.97 \%$ の合金のみ時効硬化の山が顕著であるが， $3.50 \%$ および5.60\%の Mg 量の合金ではかたさの変化はほと んど認められない。そこで，これらの合金の時効初期， 時効硬化および過時効の各過程における各試料につい て, 引張加工時のランダム・マーキング発生の有無をし らべた。Table 3 は, Fig. 2 の時効曲線の各過程におけ る引張加工時のランダム・マーキングの有無を示した表 である。Table 3 から， 時効硬化の山が顕著に表われ る $\mathrm{Mg}$ 量の多い $\mathrm{Al}-7.97 \% \mathrm{Mg}$ 合金では, 時効初期の溶 体化処理直後からランダム・マーキングが発生するが, 硬化が開始すると同時に消滅し, その後の時効でも再び 表われることはない。これに反して, 時効硬化の山が判 然と表われない $\mathrm{Mg}$ 量の少ない $\mathrm{Al}-3.50 \% \mathrm{Mg}$ 抢よび $\mathrm{Al}-$

Table 3 Stretching characteristic of heat-treated alloys

\begin{tabular}{|c|c|c|}
\hline Specimen Number & Heat Treatment & $\begin{array}{c}\text { Appearance of } \\
\text { Specimens } \\
\text { during stretching } \\
(\text { Extension } 0 \sim 2 \%)\end{array}$ \\
\hline $\begin{array}{c}\text { No. } 4 \\
(3.50 \% \mathrm{Mg})\end{array}$ & $\begin{array}{l}1 \mathrm{hr} . \text { at } 300^{\circ} \mathrm{C} \text {; W.Q. } \\
2 \mathrm{hrs} \text { at } 350^{\circ} \mathrm{C} \text {; W.Q.; aged } 60 \mathrm{~min} \text { at } 200^{\circ} \mathrm{C} \\
2 \text { hrs. at } 350^{\circ} \mathrm{C} \text {; W.Q.; aged } 20 \text { days at } 200^{\circ} \mathrm{C} \\
2 \text { hrs. at } 350^{\circ} \mathrm{C} \text {; W.Q.; aged } 70 \text { days at } 200^{\circ} \mathrm{C}\end{array}$ & $\begin{array}{c}\text { R.M. } \\
\text { " } \\
\text { " } \\
\text { " }\end{array}$ \\
\hline $\begin{array}{c}\text { No. } 5 \\
(5.60 \% \mathrm{Mg})\end{array}$ & 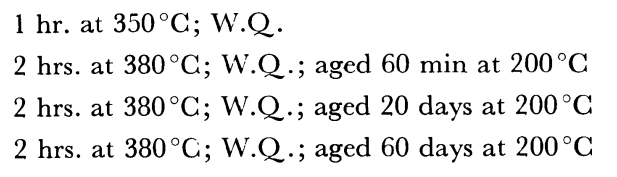 & $\begin{array}{c}\text { R.M. } \\
\text { " } \\
\text { " } \\
\text { " }\end{array}$ \\
\hline $\begin{array}{c}\text { No. } 6 \\
(7.97 \% \mathrm{Mg})\end{array}$ & 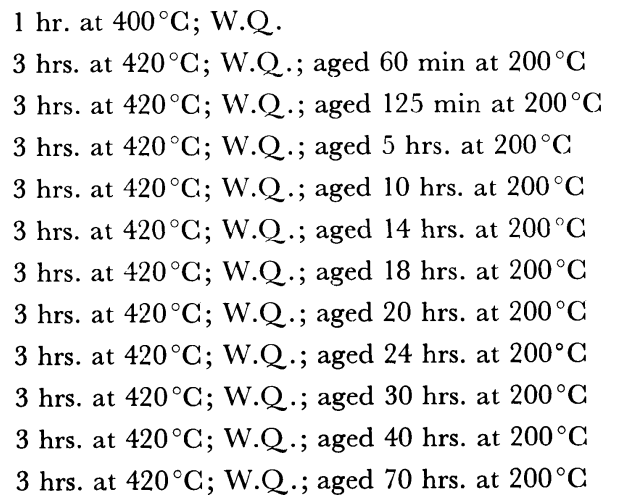 & $\begin{array}{c}\text { R.M. } \\
\quad " \\
\text { " } \\
\text { " } \\
\text { N.M. } \\
\quad " \\
\text { " } \\
\text { " } \\
\text { " } \\
\text { " } \\
\text { " } \\
\text { " }\end{array}$ \\
\hline
\end{tabular}


$5.60 \% \mathrm{Mg}$ 合金では，ランダム・マーキングが消滅する ことなく，つ权に，発生することが明らかである。

\section{Al-Mg 合金の時効過程の組織学的観察}

前節 3 では， $3.50 \%, 5.60 \%, 7.95 \% \mathrm{Mg}$ を含む 3 種 の $\mathrm{Al}-\mathrm{Mg}$ 合金の時効硬化曲線 (Fig. 2参照) に関寸る各 試料の引張加工時におけるランダム・マーキングの発生 の有無が明らかにされたが，同時に，各試料の顕鏡によ る組織学的観察の必要を認めたので, 時効過程における 析出物の挙動について観察した。Photo. 2 の組織写真 は $200^{\circ} \mathrm{C}$ の恒温時効中の $7.97 \% \mathrm{Mg}$ を含む $\mathrm{Al}-\mathrm{Mg}$ 合金 板の各過程での顕微鏡写真である。組織観察のための試 料は, 時効時間毎に水焼入れして 2 時間以内に電解研磨

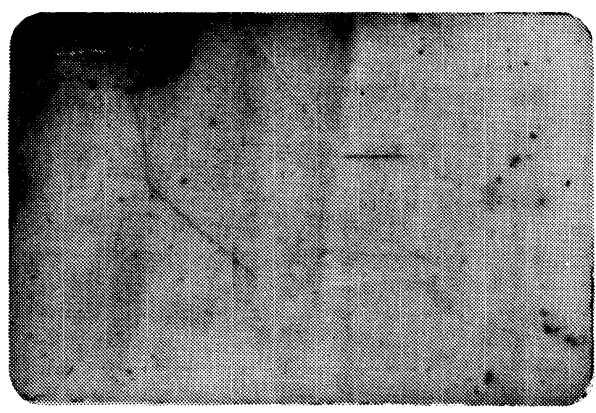

water quenched from $400^{\circ} \mathrm{C}$

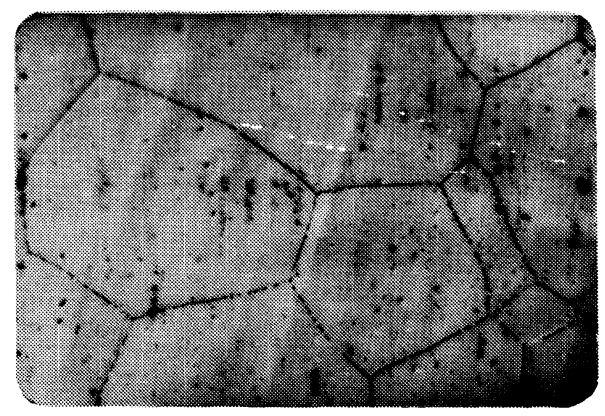

Ageing time; $5 \mathrm{hrs}$

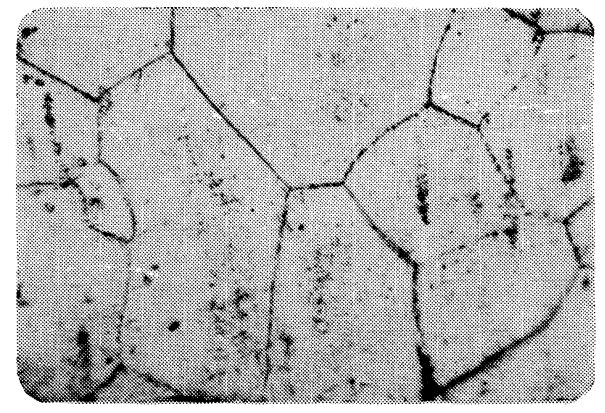

Ageing time; $15 \mathrm{hrs}$
と化学腐食によって顕鏡用試料とし，写真撮影したもの である。 $\mathrm{Al}-\mathrm{Mg}$ 合金の析出機構》によれば，この系の 析出過程は $\mathrm{Al}-\mathrm{Cu}$ 合金の析出過程の類似と見られ, [G. P. zone I. II. $\rightarrow \beta^{\prime}$ 相 $\rightarrow$ 安定相 $\beta$ ] なる過程を考えて いるが, この顕微鏡写真の倍率では, 安定相 $\beta$ の局部析 出, 全面析出および凝集状態が観察される程度である。 すなわち, 時効開始直後は少量の不純物または研磨キズ を除けば，粒界および粒内には何の変化もないが，時効 後 8〜10hrs. 頃より粒界㧍よび粒内の析出が始まり， 20 hrs. を過ぎて，硬化のピークに至れば，完全に析出相は 安定化して, 過時効の領域では凝集状態となる。これに 反して，3.50\%および $5.60 \% \mathrm{Mg}$ (Photo. 3 参照)を含 むこの系の合金は，時効開始後から $60 \mathrm{hrs.}$ を経ても $\mathrm{Al}-$ $7.97 \% \mathrm{Mg}$ 合金の組織写真に表われたような顕著な変化 はないようである。いずれにしても， Mg 量の多い $\mathrm{Al}-$ $7.97 \% \mathrm{Mg}$ 合金については, 引張加工時に発生するラン ダム・マーキングが，時効過程の析出開始以後は析出物 の安定凝集にいたるまで，完全に消隇するので，ランダ ム・マーキングの発生は, 時効過程における析出状態に 左右されるようである。

\section{5. 銅添加による影響}

Hooper ${ }^{1)}$ はまた Al-Cu-Mg 合金の焼入れ材にランダ ム・マーキングが発生し, その後の時効で消滅したと報

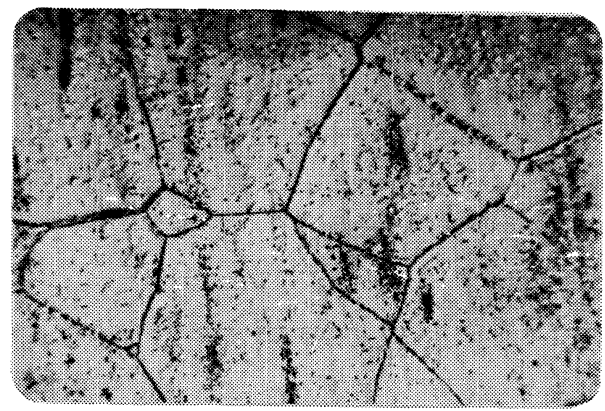

Ageing time; $20 \mathrm{hrs}$

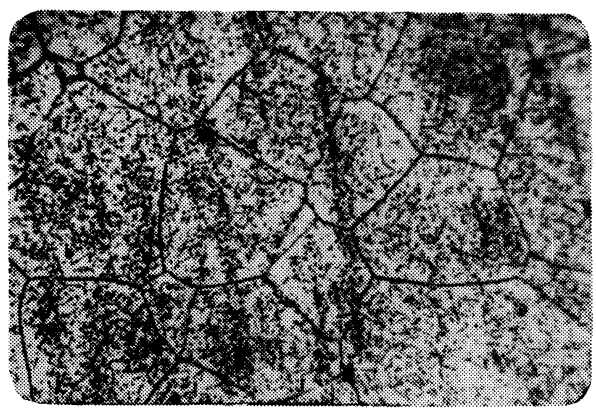

Ageing time; $55 \mathrm{hrs}$

Photo. 2 Microstructures of $\mathrm{Al}-8 \% \mathrm{Mg}$ alloy sheets. $(\times 400)$ 
告している。この事実から，Gu を添加することによつ て $8 \%$ 以下の $\mathrm{Mg}$ 量を含む $\mathrm{Al}-\mathrm{Mg}$ 合金でも，比較的 早期に，かつ，顕著に析出硬化が表われるのではないか と考えた。そこで， $\mathrm{Al}-\mathrm{Mg}$ 合金に $\mathrm{Cu} の$ の添加を試み た。Table 4 は $\mathrm{Cu}$ を添加した各種の $\mathrm{Al}-\mathrm{Mg}$ 合金の化 学組成と熱処理条件である。陚料番号 1 から 5 までのも のは $\mathrm{Cu}$ の微量添加の影響を明らかにするための標準試 料で, 試料番号 6 から10までの試料は $\mathrm{Cu}$ を添加したも のである。使用地金は $99.99 \% \mathrm{Al}, 99.99 \% \mathrm{Mg}$ および 99.9\% Cu を使用した。なお， Table 4 の化学成分值は 試料溶製時の科量值である。試験片の作製および実験方 法は 2.1項で示したものと同一である。溶体化処理温度 は $\mathrm{Al}$ に対する各 $\mathrm{Mg}$ 量の溶解度曲線上, 約 $80^{\circ} \mathrm{C}$ 程度高 い温度を採用した。

Fig. 3 は Al-8\% Mg 合金（試料番号; 5 ）扎よび $\mathrm{Al}-$ $8 \% \mathrm{Mg}-0.2 \% \mathrm{Cu}$ 合金（試料番号；10）の $200^{\circ} \mathrm{C}$ における 時効硬化曲線である。Fig. 3 から明らかなように $\mathrm{Mg}$ 含 有量の多い（7 8\%程度）この系の合金では， $\mathrm{Cu}$ 添 加により時効硬化量も多く, かつ, 硬化時期も早くなつ ているように見受けられる。

Table 4 Compositions and Heat-Treatments of specimens

\begin{tabular}{|c|c|c|c|c|}
\hline \multirow{2}{*}{$\begin{array}{c}\text { Specimen } \\
\text { Number }\end{array}$} & \multicolumn{3}{|c|}{ Nominal Composition \% } & \multirow{2}{*}{$\begin{array}{c}\text { Solution } \\
\text { Treated } \\
\text { Temperature }\end{array}$} \\
\hline & $\mathrm{Mg}$ & $\mathrm{Cu}$ & $\mathrm{Al}$ & \\
\hline 1 & 2.0 & - & Remainder & $350^{\circ} \mathrm{C} \times 2 \mathrm{hrs}$ \\
\hline 2 & 3.0 & - & " & $350^{\circ} \mathrm{C} \times 2 \mathrm{hrs}$ \\
\hline 3 & 3.5 & - & " & $350^{\circ} \mathrm{C} \times 2 \mathrm{hrs}$ \\
\hline 4 & 6.0 & - & " & $380^{\circ} \mathrm{C} \times 2 \mathrm{hrs}$ \\
\hline 5 & 8.0 & - & " & $420^{\circ} \mathrm{C} \times 2 \mathrm{hrs}$ \\
\hline 6 & 3.5 & 0.1 & " & $350^{\circ} \mathrm{C} \times 2 \mathrm{hrs}$ \\
\hline 7 & 3.5 & 0.5 & " & $350^{\circ} \mathrm{C} \times 2 \mathrm{hrs}$ \\
\hline 8 & 4.0 & 0.4 & " & $350^{\circ} \mathrm{C} \times 2 \mathrm{hrs}$ \\
\hline 9 & 6.0 & 0.2 & " & $380^{\circ} \mathrm{C} \times 2 \mathrm{hrs}$ \\
\hline 10 & 8.0 & 0.2 & " & $380^{\circ} \mathrm{C} \times 2 \mathrm{hrs}$ \\
\hline
\end{tabular}

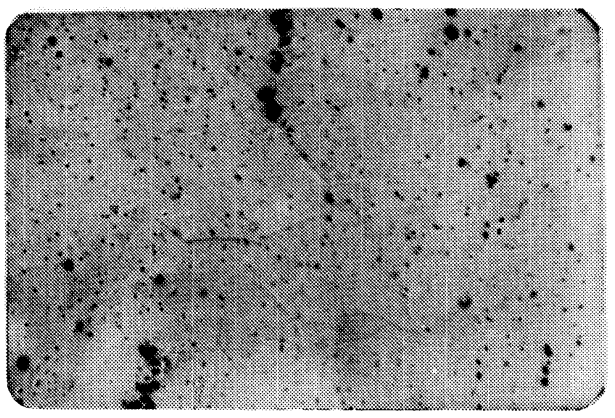

water quenched from $400^{\circ} \mathrm{C}$
Fig. 4 は Al- $6 \% \mathrm{Mg}$ 合金(拭料番号 ; 4)・Al-6\% $\mathrm{Mg}-0.2 \% \mathrm{Cu}$ 合金（試料合金：9）打よび $\mathrm{Al}-3.5 \% \mathrm{Mg}$

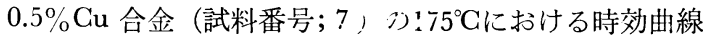
である。Fig.4から明らかなっうに，6\%以下の Mgを 含むこの系の合金は $\mathrm{Cu} \sigma$ 添加にもかかわらず，早期の 時効硬化は期待できないよへである。すなわち，140日 にわたる恒温 $\left(175^{\circ} \mathrm{C}\right)$ 時交。ではかたさに析出硬化を暗 示するような変化は見られない。さらに，図中の逆三角 のクサビ型は，その，時效時間終了直後の各試料を引張加 工した時にランダム・マーキングが発生したことを意味 する記号である。す仿わ，Mg 含有量の少ない（6\% 以下）この系の台金では，140日にわたる時効後もラン ダム・マーキンブが発生することを示している。以上の 結果では， $\mathrm{Ga}$ の微量添加は $8 \%$ 程度の高 $\mathrm{Mg}$ 量の $\mathrm{Al}-$ $M g$ 合金板については時効硬化を促進する傾 向を示す

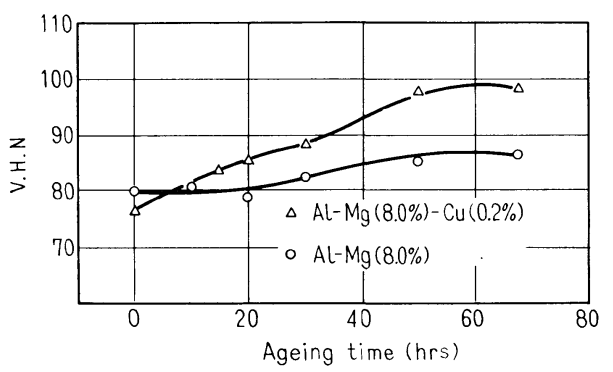

Fig. 3 Age-hardening curves of Al-Mg alloys at $200^{\circ} \mathrm{C}$.

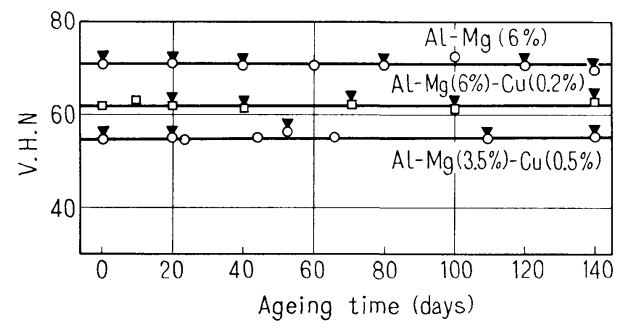

Fig. 4 Age-hardening curves of various $\mathrm{Al}-\mathrm{Mg}$ alloys at $175^{\circ} \mathrm{C}$.

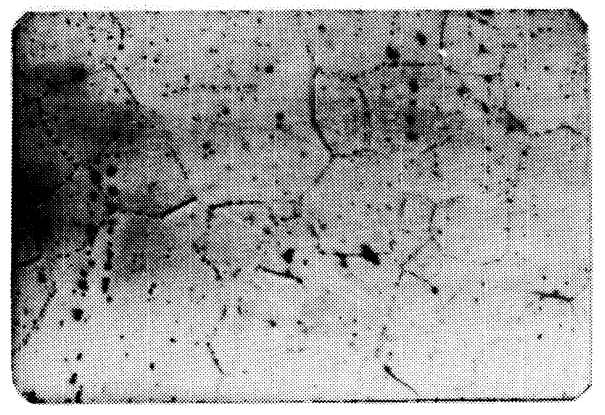

Ageing time; $60 \mathrm{hrs}$

Photo. 3 Microstructures of Al-6\% Mg alloy sheets. $(\times 400)$ 


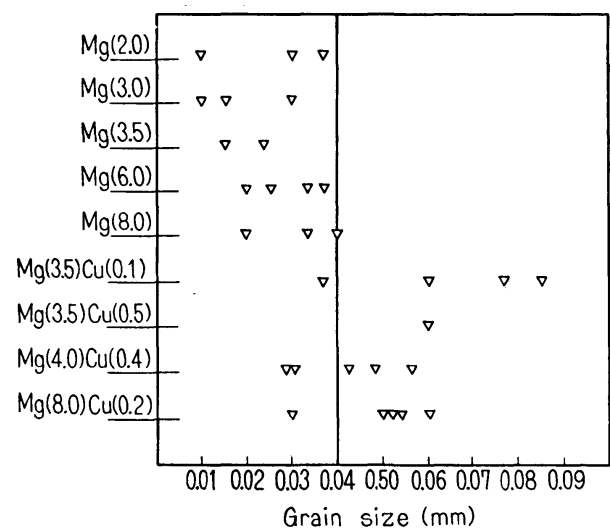

Fig. 5 Relation between additional elements and grain size of various $\mathrm{Al}-\mathrm{Mg}$ alloy sheets on which random markings were observed.

が，その他の低 $\mathrm{Mg}$ 量（6\%以下）のこの系の合金に はほとんど影響をおよぼさないようである。

Chadwick と Hooper ${ }^{3)}$ は Al-Mg 合金板の引張加工中 の初期に発生するランダム・マーキングは結晶粒度が約 $0.05 \mathrm{~mm}$ 以下の場合にのみ現われるとしている。著者 の研究結果もほぼ同様の傾向を示しているが，Cu を微 量添加したこの系の合金板のみは結晶粒度の限界值を 異にしている。これらの結果を示したのが Fig. 5 であ る。図の中で逆三角のクサビ型はランダム・マーキング の発生した板材の結晶粒度を示している。すなわち, $\mathrm{Cu}$ を含まない各種の $\mathrm{Al}-\mathrm{Mg}$ 合金板のランダム・マー キングはすべて結晶粒度 $0.04 \mathrm{~mm}$ 以下の板材において のみ発生しているが，Cu を微量添加したものは，ラン ダム・マーキングの発生粒度限界值が明らかに結晶粒の 大きい範囲までずれているのがわかる。この発生粒度限 界值といらのはランダム・マーキングが発生する最大の 結晶粒度と考えればよい。これを別の見方をしたのが Fig. 6 で, Fig. 5 で示した各種の合金中， $\mathrm{Al}-6 \% \mathrm{Mg}$ $0.2 \% \mathrm{Cu}$ 合金板について溶体化処理温度と結晶粒度との 関係を示したものである。斜線で示された部分はランダ ム・マーキングの発生域で, この系の合金板の引張加工 時の初期に発生するランダム・マーキングを除去するた めには，この斜線の領域以外の熱処理条件を考えるべき ことを暗示している。

\section{6. むすび}

$\mathrm{Al}-\mathrm{Mg}$ 系の合金板の引張加工時に発生する引張 歪 模 様の中, 加工初期に発生するランダム・マーキングの発生 条件を主として研究した。その結果, 引張歪模様に関す るこれまでの報告1) 4) とは異なる二，三の新しい事実が 見出された。それなどを要約すると以下のと拈りである。

1）引張加工の際に発生するランダム・マーキング

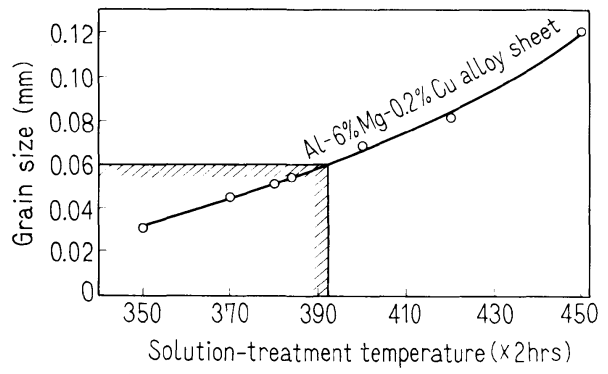

Fig. 6 Relation between solution-treatment temperature and grain size of $\mathrm{Al}-6 \% \mathrm{Mg}-0.2 \% \mathrm{Cu}$ alloy sheet.

は，一般に， 0.04〜0.05 $\mathrm{mm}$ 以下の細かい結晶粒から なる再結晶した材料に発生し，あらい結晶粒，とくに， $0.1 \mathrm{~mm}$ 以上の材料では発生を見ない。

2）燒入れ状態でもランダム・マーキングは発生す る。ただし, $\mathrm{Mg}$ 量 $8 \%$ 程度の材料はその後の恒温時効 $\left(200{ }^{\circ} \mathrm{G}\right)$ により時効硬化し，硬化初期にランダム・マ ーキングは消滅し，過時効にいたるも発生しない。これ に反して, $\mathrm{Mg}$ 量 $6 \%$ 以下の材料では，恒温時効後 140 日を経てもランダム・マーキングは，常に発生する。

3） $\mathrm{Cu}$ の添加 $(0.1 \sim 0.5 \%)$ はランダム・マーキン グの発生限界粒度 $(0.04 \sim 0.05 \mathrm{~mm})$ を上まわる傾向 を 示す。

4） $\mathrm{Cu}$ の添加は $8 \%$ Mg を含む $\mathrm{Al}-\mathrm{Mg}$ 合金では 時効硬化を促進する傾向があるが， $6 \%$ 以下の $\mathrm{Mg}$ を 含むこの系の合金にはそのような傾向はない。

終わりに，この研究を行なうに際していろいろと御教 示を載いた明治大学・大野恭男教授に心からお礼を申し 上げる。

\section{参 考 文 献}

1) W. H. L. Hooper; J. Inst. Metals, (1952 53), $81,563$.

2) G. A. Knight and G. Murray; Sheet Metal Ind., (1946), 23, 1741.

3) R. Chadwick and W. H. L. Hooper; J. Inst. Metals, (1951 52), 80, 17.

4) V. A. Phillps, A. J. Swain and R. Eborall; J. Inst. Metals (1952 53), 81, 625.

5) Raynor; Annotated Eguilibrium Diagram Series No. 5, (1946).

6) O. Dhl und K. Detert; Z. Metallkunde, (1955), 46, No. 2.

7) E. C. W. Perryman and G. B. Drook; J. Inst.

Metals (1950), 78. 19 34.

8) 三島;軽金属 No. 17, (1955), 36

9) Metal Handbook, (1948) 